\title{
Interannual modulation of seasonal glacial velocity variations in the Eastern Karakoram detected by ALOS-1/2 data - ERRATUM
}

\section{Erratum}

Cite this article: Usman M, Furuya M (2020). Interannual modulation of seasonal glacial velocity variations in the Eastern Karakoram detected by ALOS- $1 / 2$ data - ERRATUM. Journal of Glaciology 66(259), 889. https:// doi.org/10.1017/jog.2020.63

First published online: 28 July 2020
Muhammad Usman and Masato Furuya

https://doi.org/10.1017/jog.2018.39, Published by Cambridge University Press, 11 May 2018.

Some figure numbers published in the article are wrong and we correct them here.

\section{Study Area}

In the third last paragraph of this section the Figure number should be:

(Figs 1, 2c) $\rightarrow$ (Figs 1, 4c)

\subsection{Baltoro Glacier}

In this whole subsection, we are referring to Figure 2. Therefore, the Figure numbering should be changed:

Fig $3 \rightarrow$ Fig 2 (for the whole subsection)

\subsection{Siachen Glacier}

In this whole subsection, we are referring to Figure 3. Therefore, the Figure numbering should be changed:

Fig $4 \rightarrow$ Fig 3 (for the whole subsection)

\subsection{Kundos Glacier}

In this whole subsection, we are referring to Figure 4. Therefore, the Figure numbering should be changed:

Fig $2 \rightarrow$ Fig 4 (for the whole subsection)

\subsection{Role of hydrological and thermal control mechanisms for flow instability in the Karakoram Range}

Here, in the third last paragraph, we are referring to Figure $4 \mathrm{~b}$. Therefore, the Figure numbering should be changed:

Fig. $2 \mathrm{~b} \rightarrow$ Fig. $4 \mathrm{~b}$

\section{Reference}

Usman M and Furuya M (2018) Interannual modulation of seasonal glacial velocity variations in the Eastern Karakoram detected by ALOS-1/2 data. Journal of Glaciology 64(245), 465-476 (doi: 10.1017/jog.2018.39) (c) The Author(s) 2020. This is an Open Access article, distributed under the terms of the Creative Commons Attribution-NonCommercialNoDerivatives licence (http://creativecommons. org/licenses/by-nc-nd/4.0/), which permits non-commercial re-use, distribution, and reproduction in any medium, provided the original work is unaltered and is properly cited. The written permission of Cambridge University Press must be obtained for commercial re-use or in order to create a derivative work. 